\title{
REMOVAL OF MALACHITE GREEN DYE FROM AQUEOUS SOLUTION USING MULTI-WALLED CARBON NANOTUBES: AN APPLICATION OF EXPERIMENTAL DESIGN
}

\author{
(Penyingkiran Malakit Hijau daripada Larutan Akues Menggunakan Karbon Tiub Nano: \\ Aplikasi Reka Bentuk Eksperimen) \\ Siti Aminah Zulkepli ${ }^{1}$, Md Pauzi Abdullah ${ }^{1,2 *}$, Wan Mohd Afiq Wan Mohd Khalik ${ }^{1}$ \\ ${ }^{I}$ School of Chemical Sciences and Food Technology \\ ${ }^{2}$ Centre for Water Research and Analysis (ALIR) \\ Faculty of Science and Technology \\ Universiti Kebangsaan Malaysia, 43600 UKM Bangi, Selangor, Malaysia \\ *Corresponding author: mpauzi@ukm.edu.my
}

Received: 11 January 2016; Accepted: 10 March 2016

\begin{abstract}
An experimental design methodology was performed in the optimization of removal of malachite green dye by multi-walled carbon nanotubes. A Central Composite Design $\left(2^{5}\right)$ was chosen to develop a mathematical model and determine the optimum condition for adsorption of malachite green by carbon nanotubes. Five experimental factors, namely initial dye concentration, mass of adsorbent, $\mathrm{pH}$, contact time and agitation speed were studied. Maximum adsorption of malachite green was achieved at the suggested optimum conditions: initial dye concentration $(20 \mathrm{ppm})$, weight of adsorbent $(0.03 \mathrm{~g})$, $\mathrm{pH}$ solution (7) contact time (17 $\mathrm{min})$ and agitation speed (150 strokes per min). The experimental value of adsorption by multi-walled carbon nanotubes were found to be in good agreement with the predicted value $\left(\mathrm{R}^{2}=0.922\right)$. The experimental equilibrium data were best fitted to isotherm model (Langmuir) and kinetic model (pseudo second-order) respectively. Maximum adsorption by carbon nanotubes at monolayer for malachite green was obtained at $112.36 \mathrm{mg} / \mathrm{g}$ while kinetic rate constant was calculated to be $0.0017 \mathrm{~g} \mathrm{mg}^{-1} \mathrm{~min}^{-1}$.
\end{abstract}

Keywords: carbon nanotubes, adsorption, malachite green, experimental design

\begin{abstract}
Abstrak
Metodologi reka bentuk eksperimen telah dijalankan dalam pengoptimuman penyingkiran pewarna malakit hijau oleh karbon tiub nano multi-dinding. Reka bentuk komposit berpusat $\left(2^{5}\right)$ telah dipilih untuk membentuk satu model matematik dan menentukan kondisi yang optima untuk penjerapan malakit hijau oleh karbon tiub nano. Lima faktor eksperimen yang terdiri daripada kepekatan awal pewarna, berat bahan penjerap, $\mathrm{pH}$ larutan, masa sentuhan dan kelajuan goncangan telah dikaji. Malakit hijau telah mencapai penjerapan yang optima oleh karbon tiub nano pada kondisi: kepekatan awal pewarna (20 ppm), berat bahan penjerap (0.03 g), $\mathrm{pH}$ larutan (7), masa sentuhan (17 minit) dan kelajuan goncangan (150 strok/minit). Nilai eksperimen untuk penjerapan oleh karbon tiub nano multi-dinding telah mencapai persetujuan yang baik pada nilai jangkaan $\left(\mathrm{R}^{2}=0.922\right)$. Data eksprimen keseimbangan menunjukkan kesesuaian pada model Langmuir dan model pseudo tertib kedua. Penjerapan maksimum oleh karbon tiub nano pada monolapisan untuk malakit hijau ialah $112.36 \mathrm{mg} / \mathrm{g}$ manakala pemalar kadar kinetik ialah $0.0017 \mathrm{~g} \mathrm{mg}^{-1} \mathrm{~min}^{-1}$.
\end{abstract}

Kata kunci: karbon tiub nano, penjerapan, malakit hijau, reka bentuk eksperimen 


\section{Siti Aminah et al: REMOVAL OF MALACHITE GREEN DYE FROM AQUEOUS SOLUTION USING MULTI-WALLED CARBON NANOTUBES: AN APPLICATION OF EXPERIMENTAL DESIGN}

\section{Introduction}

The wide consumption of dyes in textile industries has produced a large amount of waste in the environment. There are structural varieties of dyes such as acidic, basic, disperse, azo, diazo, metal complex and anthraquinone that have been utilized in industries [1]. Malachite Green (MG) is a N-dimethylated diaminotriphenyl-methane dye that was first introduced during the mid-1933s [2] and is extensively used in aquaculture and dyes industries. MG is a basic dye, readily soluble in water and has been used as a dye in silk, jute, leather, cotton, paper and acrylic industries as well as food colouring agent, food additive, medical disinfectant and anthelmintic [3]. In aquaculture, MG has been used as an effective antifungal and antiprotozoal agent. The fungicidal properties of MG can control fungal attack, protozoan infections and some other diseases in aquatic organisms [4].

Even though MG was not approved by the US Food and Drug Administration, it is still being consumed around the world since it is relatively inexpensive, ready to be used and highly efficacious [5]. The disposal of MG in the environment can cause environmental problems, especially water pollution. MG is classified as a Class II Health Hazard and shows significant health risk to human through consumption of fish that contains MG residue [6]. MG is easily absorbed by fishes after treatment and reduced in the tissues of fish to its colourless metabolite compound known as leucomalachite green (LMG), which is also a suspected mutagen and teratogen [7]. LMG excretes very slow ( $\mathrm{t}^{1 / 2} \sim 40$ days) in certain fatty tissues and this causes the accumulation of LMG in fishes [8]. In addition, MG can cause harm to the aquatic environment; in a way, it is reducing light penetration and photosynthesis $[9,10]$. The disposal of dye wastewater without proper treatment is a big challenge since most of the dyes are difficult to eliminate from the environment and dyes are usually hard to biodegrade due to their complex molecular structures [11].

Various techniques have been applied for the removal of MG from wastewater, which included physical, chemical and biological methods. Chemical techniques such as advanced oxidation process consumed more chemical reagent while high cost of chemicals and operation brought about this method as an unattractive option. Meanwhile, biological methods, which include microbial degradation, bioremediation system and fungal discoloration, do not usually achieve a satisfactory elimination of the dyes on a continuous basis and require longer time [9, 12]. Adsorption, which is one of the physical techniques for wastewater treatment, becomes an appealing method in the removal of dyes from wastewater since it offers a simple and easy design, does not contribute to harmful substances, has high efficiency and versatile techniques compared to the others [13].

Recently, carbon nanotubes (CNTs) have been recognized to have a potential to be a superior adsorbent in the adsorption of dye from wastewater because of the unique chemical and physical properties of CNTs. Generally, CNTs are divided into two types, namely single-walled carbon nanotubes (SWCNT) and multi-walled carbon nanotubes (MWCNT). CNTs consist of highly porous and hallow structure, large specific surface area, light mass density and provide a chemically inert surface for physical adsorption. These tremendous morphologies have given an advantage for a good adsorption $[14,15]$, thus an efficient removal of contaminants. CNTs have been successfully applied to remove numerous contaminants in wastewater such as heavy metals [16,17], volatile organic compound [18] and dye $[10,15,19,20]$.

Optimization of adsorption studies can be performed by varying experimental factors and conventionally, the classical method has limitations as it only can vary one factor at one time while the other factors are fixed. In addition, it requires a large number of experiments to be performed each time. Meanwhile, the response surface methodology (RSM) is one of the approaches by the researchers to study the interaction of several factors at one time. RSM is a collection of mathematical and statistical techniques in which describing the response to the experimental data fitted in a polynomial equation and the experimental data were achieved by the systematic design [21]. Designing and evaluating experiments by experimental design allows the researchers to optimize the interest factors for the adsorption process and depict the linear, interaction and quadratics effects of all factors involved at the same time. The systematically varied design by RSM also controls and reduces the number of experiments. Beneficially, this made the research become faster, more economical and effective compared to the classical method, which consumes more chemicals and time [21,22]. 
In the present study, a central composite design (CCD) has been chosen to be applied in the optimization of MG removal by MWCNTs. The batch experiments under optimized conditions were then tested for isotherm and kinetic model respectively.

\section{Reagents and Instruments}

\section{Materials and Methods}

Multi-walled Carbon Nanotubes ( 6 - $9 \mathrm{~nm}$ outer diameter, $5 \mu \mathrm{m}$ in length and $>95 \%$ purity) were purchased from Sigma-Aldrich (St. Louis, USA) and have been used for adsorption experiment without further purification. The malachite green dye, sodium acetate with analytically graded was purchased from R \& M Chemicals (Essex, UK). Acetic acid used for preparation of acidic buffer (Merck, Germany) and for basic buffer, ammonium hydroxide from J. T. Baker (Pennsylvania, USA) and ammonium chloride from Ridel-De Haen (Seelze, Germany) were used. Deionized water was obtained from a Milli-Q EasypureRodi system (Barnstead, USA).

The initial and final concentrations of malachite green were determined by UV-Vis spectrophotometer (Shimadzu Model UV-1650PC) at a wavelength of $617 \mathrm{~nm}$. The $\mathrm{pH}$ measurements were carried out by using $\mathrm{pH}$ meter (Eutech Model pH 700 series). An agitation effect was performed by shaking water bath (Memmert WNB 22). The cellulose nitrate membrane filter with pore size $0.45 \mu \mathrm{m}$ produced by Millipore (Merck, Germany) was used for filtering MWCNTs from aqueous solution after adsorption experiment.

\section{Adsorption Experiments}

The stock solution of malachite green was prepared by weighing the appropriate mass of malachite green dye salt and dissolved with deionized water. Then, working solutions of malachite green were prepared by diluting volume of stock solution required with deionized water.

In general, the adsorption of malachite green was performed as follows: A specified mass of MWCNTs powder was added into $100 \mathrm{~mL}$ of MG solution. The $\mathrm{pH}$ of the solution was adjusted with a buffer solution of acetate acid-sodium acetate and ammonium hydroxide-ammonium chloride. Then, each of the solution was shaken in a shaker for a specific time which following the designed experiments (Table 2) and the adsorption experiments were carried out based on central composite design (CCD). The MWCNTs then was filtered using vacuum filter, and the filtrate solution was analyzed to UV-Vis spectrophotometer to determine the final concentration of the dye.

\section{Central Composite Design}

A central composite design $\left(2^{5}\right)$ was used to evaluate the implication and influence of variables toward the removal of dye by MWCNTs. The efficiency of malachite green adsorption by MWCNTs was observed by different experimental factors, namely mass of adsorbent, initial concentration of dye, $\mathrm{pH}$ of solution, contact time and agitation speed (Table 1). A total of 54 experiments were designed by using Minitab Software version 17 (Minitab Inc., State College, USA). The mathematical relationship between the factors can be approximated by the second order polynomial model as expressed in Eq. 1 [23]:

$$
y=\beta_{0}+\sum_{i=1}^{5} \beta_{i} x_{i}+\sum_{i=1}^{5} \sum_{j=1}^{5} \beta_{i j} x_{i} x_{j}+\sum_{i=1}^{5} \beta_{i i} x_{i}^{2}
$$

where $y$ is the predicted response (percentage of removal); $x_{i}{ }^{\prime} s$ are the input variables (mass of adsorbent, initial concentration of dye, $\mathrm{pH}$ of solution, contact time and agitation speed) that are known for each experimental run. The parameter $\beta_{0}$ is the model constant; $\beta_{\mathrm{i}}$ is the linear coefficient; $\beta_{\mathrm{ii}}$ is the quadratic coefficient and $\beta_{\mathrm{ij}}$ is the cross-product coefficient. Generally, CCD consists of three operations which are $2 n$ axial run, $2^{n}$ factorial run and central run. The CCD in present research is designed based on carrying out 12 axial points, 32 factorial point and 12 replicates at the center (54 experiments) as listed in Table 2. Total of experiments can be calculated by Eq. 2 below:

$$
\text { Total number of experiments }=2 n+2^{n}+n_{c}
$$


Siti Aminah et al: REMOVAL OF MALACHITE GREEN DYE FROM AQUEOUS SOLUTION USING MULTI-WALLED CARBON NANOTUBES: AN APPLICATION OF EXPERIMENTAL DESIGN

where $n$ is the number of factors, $n_{c}$ is the number of center points [24].

Table 1. Experimental factors and levels in the CCD

\begin{tabular}{lccccc}
\hline \multirow{2}{*}{ Factors } & \multicolumn{3}{c}{ Levels } & \multicolumn{3}{c}{$\begin{array}{c}\text { Star point } \\
\boldsymbol{\alpha}= \pm \mathbf{2 . 0 0}\end{array}$} \\
\cline { 2 - 6 } & $\begin{array}{c}\text { Low } \\
\mathbf{( - 1 )}\end{array}$ & $\begin{array}{c}\text { Central } \\
\mathbf{( 0 )}\end{array}$ & $\begin{array}{c}\text { High } \\
\mathbf{( + 1 )}\end{array}$ & $\mathbf{- \alpha}$ & $+\boldsymbol{\alpha}$ \\
\hline $\left.\mathrm{X}_{1}\right)$ Mass of adsorbent $(\mathrm{g})$ & 0.04 & 0.06 & 0.08 & 0.02 & 0.10 \\
$\left(\mathrm{X}_{2}\right)$ Initial concentration of & 40 & 60 & 80 & 20 & 100 \\
MG (ppm) & & & & & \\
$\left(\mathrm{X}_{3}\right) \mathrm{pH}$ of solution & 5.5 & 7 & 8.5 & 4 & 10 \\
$\left(\mathrm{X}_{4}\right)$ Contact time (min) & 15 & 20 & 25 & 10 & 30 \\
$\left(\mathrm{X}_{5}\right)$ Agitation speed & 60 & 90 & 120 & 30 & 150 \\
(stroke/min) & & & & & \\
\hline
\end{tabular}

Analysis of variance (ANOVA) was also performed to discriminate the significance of the variables. Interaction between latent experimental factors was visualized using surface plot graph.

\section{Measurement of Dye Concentration}

The malachite green removal for each experiment was calculated using the following Eq. 3 [25]:

$$
\% \text { MG removal }=\frac{\left(\mathrm{C}_{0}-\mathrm{C}_{\mathrm{t}}\right)}{\mathrm{C}_{0}} \times 100
$$

where $\mathrm{C}_{0}(\mathrm{mg} / \mathrm{L})$ is the initial concentration of dye, $\mathrm{C}_{\mathrm{t}}(\mathrm{mg} / \mathrm{L})$ is the concentration at time $\mathrm{t}$. The amount of adsorbed malachite green, $\mathrm{Q}_{\mathrm{e}}(\mathrm{mg} / \mathrm{g})$ was calculated by using the following Eq. 4 [26]:

$$
\mathrm{Q}_{\mathrm{e}}=\frac{\left(\mathrm{C}_{0}-\mathrm{C}_{\mathrm{e}}\right) \mathrm{V}}{\mathrm{m}}
$$

where $\mathrm{C}_{0}$ and $\mathrm{C}_{\mathrm{e}}(\mathrm{mg} / \mathrm{L})$ are the initial dye concentrations and equilibrium dye concentrations in aqueous solution respectively, $\mathrm{V}(\mathrm{L})$ is volume of the solution and $\mathrm{m}(\mathrm{g})$ is mass of the adsorbent.

\section{Isotherm and Kinetic Study}

In identifying the isotherm and kinetics of MG adsorption by MWCNTs, adsorption experiments were performed in 250 -mL conical flask with $100 \mathrm{~mL}$ of MG solution. The initial concentration of MG was varied in a range from 20 to $60 \mathrm{ppm}$ and the other parameters were kept constant for isotherm experiment. For kinetic study, a series of experiment was carried out with different contact times from adsorption while the others parameters were under optimized condition.

\section{Optimization of Adsorption Condition}

\section{Results and Discussion}

A total of 54 experiments were run according to the Central Composite Design and their responses are presented in Table 2. 
Table 2. Runs order of adsorption experiment by CCD

\begin{tabular}{|c|c|c|c|c|c|c|}
\hline Runs & $X_{1}$ & $\mathbf{X}_{2}$ & $\mathbf{X}_{3}$ & $X_{4}$ & $X_{5}$ & Removal (\%) \\
\hline 1 & -1 & -1 & -1 & -1 & -1 & 21.97 \\
\hline 2 & 1 & 1 & -1 & -1 & -1 & 53.95 \\
\hline 3 & 1 & -1 & 1 & -1 & -1 & 81.57 \\
\hline 4 & -1 & 1 & 1 & -1 & -1 & 32.99 \\
\hline 5 & 1 & -1 & -1 & 1 & -1 & 80.19 \\
\hline 6 & -1 & 1 & -1 & 1 & -1 & 39.58 \\
\hline 7 & -1 & -1 & 1 & 1 & -1 & 78.22 \\
\hline 8 & 1 & 1 & 1 & 1 & -1 & 71.34 \\
\hline 9 & 1 & -1 & -1 & -1 & 1 & 99.49 \\
\hline 10 & -1 & 1 & -1 & -1 & 1 & 52.80 \\
\hline 11 & -1 & -1 & 1 & -1 & 1 & 63.05 \\
\hline 12 & 1 & 1 & 1 & -1 & 1 & 96.39 \\
\hline 13 & -1 & -1 & -1 & 1 & 1 & 79.44 \\
\hline 14 & 1 & 1 & -1 & 1 & 1 & 88.42 \\
\hline 15 & 1 & -1 & 1 & 1 & 1 & 100.00 \\
\hline 16 & -1 & 1 & 1 & 1 & 1 & 68.30 \\
\hline 17 & 0 & 0 & 0 & 0 & 0 & 66.36 \\
\hline 18 & 0 & 0 & 0 & 0 & 0 & 67.28 \\
\hline 19 & 0 & 0 & 0 & 0 & 0 & 69.19 \\
\hline 20 & 0 & 0 & 0 & 0 & 0 & 67.97 \\
\hline 21 & 1 & -1 & -1 & -1 & -1 & 57.83 \\
\hline 22 & -1 & 1 & -1 & -1 & -1 & 36.90 \\
\hline 23 & -1 & -1 & 1 & -1 & -1 & 53.22 \\
\hline 24 & 1 & 1 & 1 & -1 & -1 & 86.48 \\
\hline 25 & -1 & -1 & -1 & 1 & -1 & 37.11 \\
\hline 26 & 1 & 1 & -1 & 1 & -1 & 51.75 \\
\hline 27 & 1 & -1 & 1 & 1 & -1 & 94.83 \\
\hline 28 & -1 & 1 & 1 & 1 & -1 & 44.26 \\
\hline 29 & -1 & -1 & -1 & -1 & 1 & 65.47 \\
\hline 30 & 1 & 1 & -1 & -1 & 1 & 80.85 \\
\hline 31 & 1 & -1 & 1 & -1 & 1 & 100.00 \\
\hline 32 & -1 & 1 & 1 & -1 & 1 & 63.13 \\
\hline 33 & 1 & -1 & -1 & 1 & 1 & 99.49 \\
\hline 34 & -1 & 1 & -1 & 1 & 1 & 70.09 \\
\hline 35 & -1 & -1 & 1 & 1 & 1 & 92.63 \\
\hline 36 & 1 & 1 & 1 & 1 & 1 & 97.24 \\
\hline 37 & 0 & 0 & 0 & 0 & 0 & 70.45 \\
\hline 38 & 0 & 0 & 0 & 0 & 0 & 72.09 \\
\hline 39 & 0 & 0 & 0 & 0 & 0 & 63.62 \\
\hline 40 & 0 & 0 & 0 & 0 & 0 & 76.53 \\
\hline 41 & -2 & 0 & 0 & 0 & 0 & 17.25 \\
\hline 42 & 2 & 0 & 0 & 0 & 0 & 80.87 \\
\hline 43 & 0 & -2 & 0 & 0 & 0 & 90.49 \\
\hline 44 & 0 & 2 & 0 & 0 & 0 & 72.75 \\
\hline 45 & 0 & 0 & -2 & 0 & 0 & 64.28 \\
\hline 46 & 0 & 0 & 2 & 0 & 0 & 96.99 \\
\hline 47 & 0 & 0 & 0 & -2 & 0 & 50.19 \\
\hline 48 & 0 & 0 & 0 & 2 & 0 & 60.30 \\
\hline 49 & 0 & 0 & 0 & 0 & -2 & 48.64 \\
\hline 50 & 0 & 0 & 0 & 0 & 2 & 88.73 \\
\hline
\end{tabular}


Siti Aminah et al: REMOVAL OF MALACHITE GREEN DYE FROM AQUEOUS SOLUTION USING MULTI-WALLED CARBON NANOTUBES: AN APPLICATION OF EXPERIMENTAL DESIGN

Table 3 (cont'd). Runs order of adsorption experiment by CCD

\begin{tabular}{ccccccc}
\hline Runs & $\mathbf{X}_{\mathbf{1}}$ & $\mathbf{X}_{\mathbf{2}}$ & $\mathbf{X}_{\mathbf{3}}$ & $\mathbf{X}_{\mathbf{4}}$ & $\mathbf{X}_{\mathbf{5}}$ & Removal (\%) \\
\hline 51 & 0 & 0 & 0 & 0 & 0 & 62.44 \\
52 & 0 & 0 & 0 & 0 & 0 & 68.08 \\
53 & 0 & 0 & 0 & 0 & 0 & 73.59 \\
54 & 0 & 0 & 0 & 0 & 0 & 73.52 \\
\hline
\end{tabular}

An empirical relationship between the response and independent variables was obtained based on results and expressed by the following second-order polynomial Eq. 5 :

$$
\begin{aligned}
\mathrm{Y}= & 69.18+14.04 \mathrm{X}_{1}-4.98 \mathrm{X}_{2}+6.99 \mathrm{X}_{3}+4.02 \mathrm{X}_{4}+12.03 \mathrm{X}_{5}-4.32 \mathrm{X}_{1}{ }^{2} \\
& +3.81 \mathrm{X}_{2}{ }^{2}+3.57 \mathrm{X}_{3}{ }^{2}-2.79 \mathrm{X}_{4}{ }^{2}-2.74 \mathrm{X}_{1} \mathrm{X}_{4}-3.04 \mathrm{X}_{2} \mathrm{X}_{4}-3.52 \mathrm{X}_{3} \mathrm{X}_{5}
\end{aligned}
$$

where $Y$ is the percentage of MG removal, $X_{1}$ is mass of adsorbent, $X_{2}$ is the initial concentration of MG, $X_{3}$ is $p H$ of solution, $\mathrm{X}_{4}$ is contact time and $\mathrm{X}_{5}$ is agitation speed. In this equation, only variable $\mathrm{X}_{2}$ showed negative linearity, whereas the other factors showed positive linearity of the fitted model.

Table 4. Descriptive statistic of ANOVA test for CCD of MG removal by MWCNTs

\begin{tabular}{cccccc}
\hline $\begin{array}{l}\text { Source of } \\
\text { variation }\end{array}$ & $\begin{array}{c}\text { Degree of } \\
\text { freedom }\end{array}$ & $\begin{array}{c}\text { Sum of } \\
\text { square }\end{array}$ & $\begin{array}{c}\text { Mean } \\
\text { square }\end{array}$ & $\boldsymbol{F}$-Value & $\boldsymbol{p}$-Value \\
\hline Model & 12 & 19912.0 & 1659.34 & 40.15 & $\mathbf{0 . 0 0 1}$ \\
Linear & 1 & 7880.9 & 7880.93 & 190.67 & $\mathbf{0 . 0 0 1}$ \\
$\mathrm{X}_{1}$ & 1 & 992.8 & 992.79 & 24.02 & $\mathbf{0 . 0 0 1}$ \\
$\mathrm{X}_{2}$ & 1 & 1952.8 & 1952.76 & 47.25 & $\mathbf{0 . 0 0 1}$ \\
$\mathrm{X}_{3}$ & 1 & 646.2 & 646.22 & 15.63 & $\mathbf{0 . 0 0 1}$ \\
$\mathrm{X}_{4}$ & 1 & 5784.9 & 5784.89 & 139.96 & $\mathbf{0 . 0 0 1}$ \\
$\mathrm{X}_{5}$ & & & & & \\
Square & 1 & 634.8 & 634.85 & 15.36 & $\mathbf{0 . 0 0 1}$ \\
$\mathrm{X}_{1} * \mathrm{X}_{1}$ & 1 & 493.9 & 493.91 & 11.95 & $\mathbf{0 . 0 0 1}$ \\
$\mathrm{X}_{2} * \mathrm{X}_{2}$ & 1 & 432.1 & 432.06 & 10.45 & $\mathbf{0 . 0 0 2}$ \\
$\mathrm{X}_{3} * \mathrm{X}_{3}$ & 1 & 264.5 & 264.49 & 6.40 & $\mathbf{0 . 0 1 5}$ \\
$\mathrm{X}_{4} * \mathrm{X}_{4}$ & & & & & \\
$2-\mathrm{Way}_{4}$ Interaction & & 240.0 & 285.19 & 5.81 & $\mathbf{0 . 0 2 1}$ \\
$\mathrm{X}_{1} * \mathrm{X}_{4}$ & 1 & 296.4 & 700.10 & 7.17 & $\mathbf{0 . 0 1 1}$ \\
$\mathrm{X}_{2} * \mathrm{X}_{4}$ & 1 & 396.9 & 261.12 & 9.60 & $\mathbf{0 . 0 0 4}$ \\
$\mathrm{X}_{3} * \mathrm{X}_{5}$ & 1 & & & & \\
Error & & 1519.5 & 47.49 & 2.44 & 0.079 \\
Lack-of-Fit & 32 & 175.1 & 19.45 & & \\
Pure Error & 9 & 21606.6 & & & \\
Total SS & 53 & & & & \\
\hline
\end{tabular}

*Bold value is significant $\mathrm{p}<0.05$ 
To analyze the significance of each variable, analysis of variance (ANOVA) is necessary. ANOVA subdivides the total variation into two parts; variation associated with the model and the variation associated with the experimental error. These will show whether the variation from the model is significant or not when compared to the ones associated with the residual error [27]. To carry out this comparison, the $F$-values were used by calculating the ratio between mean square of the model and the residual error. Meanwhile, the $p$-values were used to check the statistical significance of each coefficient, which in turn is necessary to understand the pattern of the mutual interactions between the test variables. A $p$-value of less than 0.05 in the ANOVA table indicates the statistical significance of an effect at $95 \%$ confidence level. The test of significance of regression model for response was evaluated and the result of ANOVA is presented in Table 3.

In this study, all individual experimental factors were significant with $p$-value $<0.05$. The $p$-value of lack-of-fit shows a non-significant value (0.079) which confirms the suitability of the model with the data and the model is significant [24]. The value $\mathrm{R}^{2}$ predicted is used to measure the how the model fits with the data. A good agreement was shown by the coefficient of determination between $\mathrm{R}^{2}(0.922)$ and $\mathrm{R}^{2}$ adjusted $(0.899)$ from the fitted model. In addition to correlation coefficient, the data were also evaluated based on the plots of residual (difference between the observed and the predicted response value).
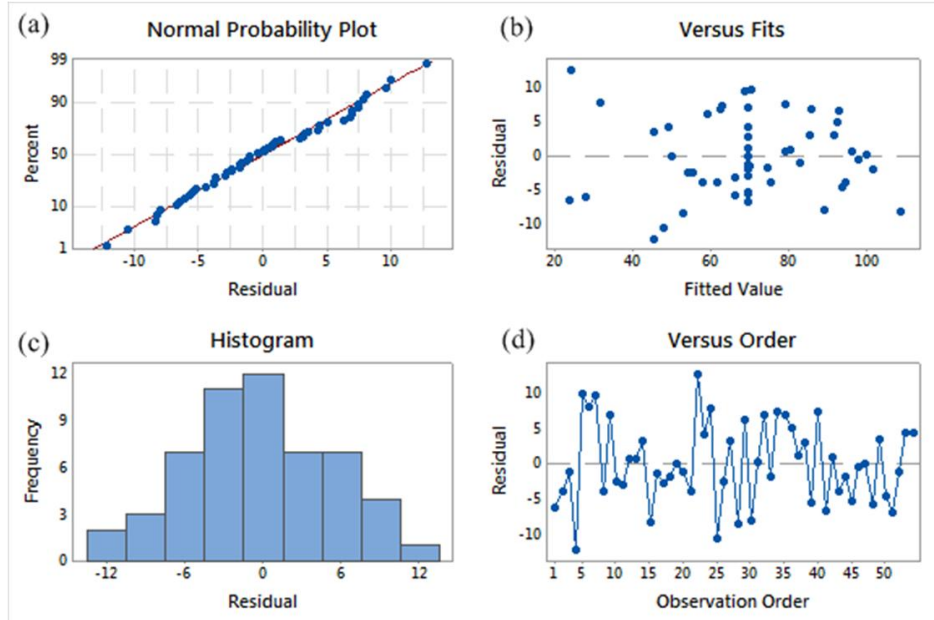

Figure 1. Residual plot for the removal of MG by MWCNTs (a) percentage of removal vs. residual, (b) residual vs. fitted value, (c) frequency vs. residual, (d) residual vs. observation order

Normal probability in Fig. 1(a) plot showed the data followed the straight line, which indicated there is normal distribution and no evidence of non-normality, skewness, outliers or undefined variables. Residuals versus fitted graph (Fig. 1(b)) can explain the consistency of the variance in errors, whereas the residual versus observation order (Fig. $1(c)$ ) is useful in identifying the effect of observation order in inducing the results when the data were collected in a different time sequence. For residual versus fitted graph and residual versus observation order graph in Fig. 1 (d), both of the graphs in this study showed the residuals randomly scattered about zero, thus signified that residuals have constant variance in error terms and data were not affected by the observation order respectively.

The curvature nature of Fig. 2 shows the response surface plots of the removal of MG by MWCNTs confirming strong interaction among latent variables. Fig. 2 (a) and 2 (d) shows the interaction of adsorbent dosage with contact time and agitation speed respectively, in influencing the removal of MG. The increase in percentage of MG removal was observed with the increase amount of adsorbent dosage. As the mass of adsorbent increasing, there are more sites and specific area for adsorption, in which provide more availability for the dye molecules to vacant on the surface of MWCNTs. 

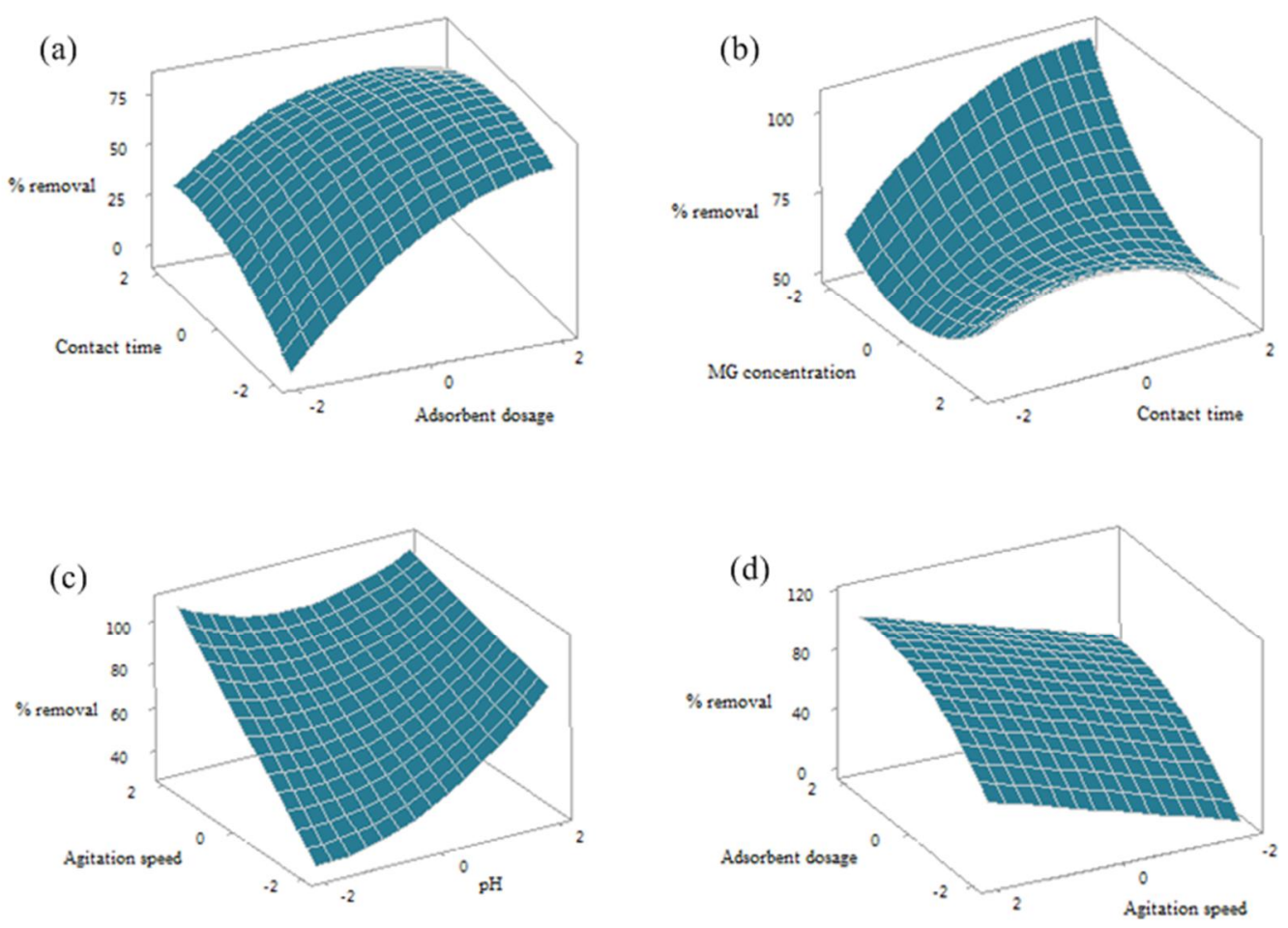

Figure 2. Surface plot for CCD: (a) contact time-adsorbent dosage; agitation speed-pH; (d) adsorbent dosage-agitation speed

(b) initial concentration MG-contact time; (c)

The response surface plots shown in Fig. 2 (b) demonstrate the changes in the percentage removal for MG initial with initial MG concentration-contact time interaction. It can be seen that the percentage of MG removal decreased when the concentration of MG increased. At lower dye concentrations, the ratio of solute concentration to adsorbent sites is lower, which increases the rate of dye uptake. However, the yield of adsorption of MG by the MWCNT decrease at higher concentration since there is no vacancy for the adsorption dye on the adsorbent as the adsorbent sites were saturated with dye molecules.

The $\mathrm{pH}$ of the system plays important roles in affecting the ability of adsorbent surface for the interaction and dye molecule tendency for binding solid surface [28]. Surface plot in Fig. 2 (c) shows the percentage of MG removal with interaction of $\mathrm{pH}$ with agitation speed. The removal of dye was more favourable at higher $\mathrm{pH}$ compared to lower $\mathrm{pH}$. This result can be clarified by the fact that at lower $\mathrm{pH}$, the presence of excess $\mathrm{H}+$ ions was competing with $\mathrm{MG}$ molecules as a cationic dye to be adsorbed on the surface of MWCNTs. However, on basic condition, the surface of the MWCNTs was enhanced with negatively charge sites and the electrostatic attraction exists between cationic dye molecules and adsorbent site [29]. The effect of contact time was illustrated by the graph in Fig. 2 (a) and 2 (b). Generally, both of surface plot show the removal of MG was increased as the contact time increased, and gradually reaching equilibrium. This is due to a lot of specific surface areas available at initial time, causing the rapid adsorption rate between MG molecules and MWCNTs. However, as the vacancies on the surface of MWCNTs were filled with MG molecules, the adsorption process becomes slower and reached equilibrium.

Another important parameter influencing the rate of adsorption is the speed of agitation. A range of agitation speed from 30 to 150 strokes/min has been studied in the adsorption experiments. As shown in surface plot in Fig. 2 (c) and 2 (d), the percentage of MG removal increased directly with increase of agitation speed. The boundary layer exists 
between adsorbent particles and solution decreasing as the speed of agitation increasing which results in the higher of dye uptake by MWCNT. Besides, high agitation speed also increases the distribution of adsorbent in solution [29].

The profile for desirable option with predicted values in the Minitab software was used for the selection of optimum conditions of the dye removal. The profile of desirable responses was chosen after specifying the desirability function (DF) for each dependent variable (removal percentage) by assigning predicted values. The scale in the range from 0.0 (undesirable) to 1.0 (very desirable) was used to achieve a global function (D) that should be maximized to obtain $100 \%$ removal by optimizing designed variables. Based on the desirability score of 1.0 , maximum removal $(99.9 \%)$ was achieved at suggested optimum conditions set as: $0.03 \mathrm{~g}$ of adsorbent, initial MG concentration of $20 \mathrm{ppm}, \mathrm{pH}$ solution of 7, with equilibrium time of 17 minutes and agitation at speed 150 strokes per minute. Three additional experiments were carried out under the optimal conditions, in which a good agreement between the calculated and experimental responses was obtained (99.9\% removal) with $2.17 \%$ of RSD value.

\section{Adsorption Isotherm Study}

Basically, isotherm analysis was performed to understand the relationship between adsorbate and the surface of adsorbent when the equilibrium is achieved. It gives useful information about mechanism, properties and tendency of adsorbate being adsorbed by the adsorbent. In this study, the data obtained during the equilibrium study were fitted to both Langmuir and Freundlich isotherm models, as a way to evaluate the equilibrium characteristics of the adsorption process.

The most basic of isotherm model was Langmuir isotherm, which assumed that there is no interaction between the adsorbate molecules and the adsorption localized in a monolayer [30]. Langmuir isotherm is expressed by the following Eq. 6:

$$
\frac{C_{e}}{Q_{e}}=\frac{1}{\left(K_{a} Q_{m}\right)}+\frac{C_{e}}{Q_{m}}
$$

where $\mathrm{C}_{\mathrm{e}}$ is the concentration of MG at equilibrium $\left(\mathrm{mg} \mathrm{L}^{-1}\right)$; $\mathrm{Q}_{\mathrm{e}}$ is the amount of dye adsorbed per mass of MWCNTs $\left(\mathrm{mg} \mathrm{g}^{-1}\right) ; \mathrm{K}_{\mathrm{L}}$ represents the Langmuir constant $\left(\mathrm{L} \mathrm{mg}^{-1}\right)$; and $\mathrm{Qm}$ is the theoretical saturation capacity of the monolayer $\left(\mathrm{mg} \mathrm{g}^{-1}\right)$ [23]. The values of $\mathrm{Q}_{\mathrm{m}}$ and $\mathrm{K}_{\mathrm{L}}$ were calculated from the intercept and slope of the linear plot of $\mathrm{C}_{\mathrm{e}} / \mathrm{Q}_{\mathrm{e}}$ versus $\mathrm{C}_{\mathrm{e}}$.

The Freundlich model is an empirical equation that assumes heterogeneous adsorption due to the diversity of adsorption sites. The Freundlich isotherm is represented by Eq. 7 below:

$$
\ln Q_{e}=\ln K_{F}+\frac{1}{n} \ln C_{e}
$$

where $\mathrm{Q}_{\mathrm{e}}$ is the amount of dye adsorbed per mass of MWCNTs ( $\left.\mathrm{mg} \mathrm{g}^{-1}\right) ; \mathrm{C}_{\mathrm{e}}$ is the concentration of MG at equilibrium $\left(\mathrm{mg} \mathrm{L}^{-1}\right) ; \mathrm{K}_{\mathrm{F}}\left(\mathrm{L} \mathrm{mg}^{-1}\right)$ and $\mathrm{n}$ are Freundlich constant, which represents the adsorption capacity and the adsorption strength respectively [23]. $\mathrm{K}_{\mathrm{F}}$ and $1 / \mathrm{n}$ were obtained from the intercept and slope of the linear plot of $\ln \mathrm{Q}_{\mathrm{e}}$ versus $\ln$ $\mathrm{C}_{\mathrm{e}}$. Table 4 summarizes the coefficient of the Langmuir and Freundlich isotherms obtained in this study.

By comparing both Langmuir and Freundlich models, it can be seen clearly that the $\mathrm{R}^{2}$ values of both models exceeded 0.9 , suggesting experimental results fitted well in both of the models. However, as $\mathrm{R}^{2}$ of Langmuir comparatively higher than Freundlich model, it can be demonstrated that the adsorption is much favourable with Langmuir model. This can be assumed that adsorbed MG molecules formed monolayer coverage on the surface of MWCNTs, and all the adsorption sites. 
Siti Aminah et al: REMOVAL OF MALACHITE GREEN DYE FROM AQUEOUS SOLUTION USING MULTI-WALLED CARBON NANOTUBES: AN APPLICATION OF EXPERIMENTAL DESIGN

Table 5. Linear regression of isotherm adsorption and its constant parameter

\begin{tabular}{lllc}
\hline Isotherm & Linear Regression & Parameter & Value of parameter \\
\hline Langmuir & $\mathrm{y}=0.0089 \mathrm{x}+0.0117$ & $Q_{m}(\mathrm{mg} / \mathrm{g})$ & 112.360 \\
& & $K_{a}(\mathrm{~L} / \mathrm{mg})$ & 0.761 \\
& & $R^{2}$ & 0.998 \\
Freundlich & $\mathrm{y}=0.1198 \mathrm{x}+4.2967$ & $1 / n$ & 0.120 \\
& & $K_{F}(\mathrm{~L} \mathrm{mg} / \mathrm{g})$ & 73.457 \\
& & $R^{2}$ & 0.933 \\
\hline
\end{tabular}

Another important parameter is separation factor, $\mathrm{R}_{\mathrm{L}}$ which is a dimensionless constant that evaluates whether the adsorption is favourable or unfavourable. The $\mathrm{R}_{\mathrm{L}}$ equation is represented as follows (Eq. 8):

$$
R_{L}=\frac{1}{\left(1+K_{l} C_{0}\right)}
$$

where $\mathrm{K}_{\mathrm{L}}$ is the Langmuir constant $\left(\mathrm{mg} \mathrm{L}^{-1}\right)$ and $\mathrm{C}_{0}$ is the initial concentration of $\mathrm{MG}$. The value of $\mathrm{R}_{\mathrm{L}}$ indicates the type of isotherm to be unfavourable $\left(R_{L}>1\right)$, linear $\left(R_{L}=1\right)$, favourable $\left(0<R_{L}<1\right)$ or irreversible $\left(R_{L}=0\right)$ [31]. All the values of $R_{L}$ ranged between 0 and 1 (shown in Fig. 3), denoting that the adsorption of MG onto MWCNTs was favourable. In addition, the $\mathrm{R}_{\mathrm{L}}$ values decreased as the initial concentration of $\mathrm{MG}$ increased, suggesting that the adsorption process was more favourable at higher concentration [32].

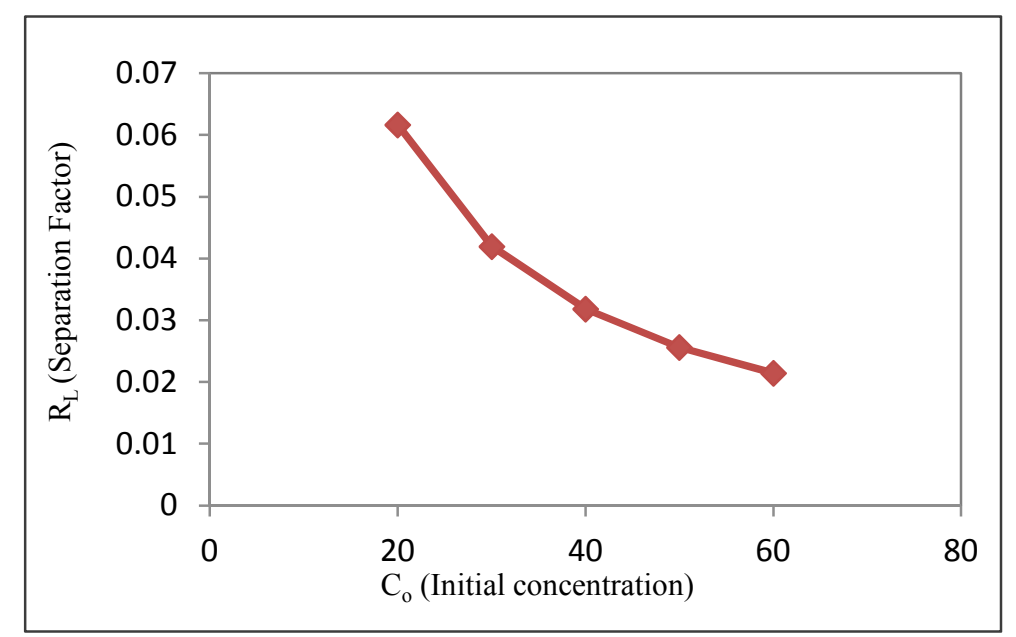

Figure 3. Separation factor, $R_{L}$ versus initial concentration of $M G, C_{0}$ for adsorption of $M G$ by $M W C N T s$

\section{Adsorption Kinetic Study}

Adsorption is a physicochemical process that involves mass transfer of solute from the solution to the surface of the adsorbent [33]. An ideal adsorption is not only having high adsorption capacity, but it also must have high rate of adsorption. Kinetic analysis does not only depict the adsorption rate of the adsorbent but also can provide important information about the mechanism of adsorption on the adsorbent. To elucidate the kinetic properties of the adsorption process of MG on MWCNTs, three most widely use kinetic models were applied, which are the pseudo-first-order, pseudo-second-order and intraparticle diffusion model. 
Generally, the pseudo-first-order model is used in explaining the adsorption rate based on the adsorption capacity. The equation of pseudo-first-order is expressed as Eq. 9 below:

$$
\log \left(Q_{e}-Q_{t}\right)=\log Q_{e}-\frac{k_{1} t}{2.303}
$$

where $\mathrm{Q}_{\mathrm{e}}$ and $\mathrm{Q}_{\mathrm{t}}$ are the amount of MG adsorbed per mass of MWCNTs $\left(\mathrm{mg} \mathrm{g}^{-1}\right)$ at equilibrium and time $\mathrm{t}(\mathrm{min})$ respectively, and $\mathrm{k}_{1}\left(\mathrm{~min}^{-1}\right)$ is rate constant of pseudo-first-order model for the adsorption [23]. Values of $\mathrm{k}_{1}$ and $\mathrm{Q}_{\mathrm{e}}$ of pseudo-first-order were obtained from the slope and intercept of plot $\log \left(Q_{e}-Q_{t}\right)$ versus $t$.

For pseudo-second-order, the equation is given as Eq. 10 below:

$$
\frac{t}{Q_{t}}=\frac{1}{k_{2} Q_{e}^{2}}+\frac{t}{Q_{e}}
$$

where $\mathrm{Q}_{\mathrm{e}}$ and $\mathrm{Q}_{\mathrm{t}}$ are the amount of dye adsorbed per mass of MWCNTs $(\mathrm{mg} / \mathrm{g})$ at equilibrium and time $\mathrm{t}(\mathrm{min})$ respectively, and $\mathrm{k}_{2}\left(\mathrm{~g} \mathrm{mg}^{-1} \mathrm{~min}^{-1}\right)$ is rate constant for pseudo-second-order model of adsorption [23]. For values of $k_{2}$ and $Q_{e}$ of pseudo-second-order, both of the values were obtained from the slope and intercept of plot $\left(t / Q_{t}\right)$ versus $\mathrm{t}$, respectively.

However, pseudo-first-order and pseudo-second-order have their own limitation as both of the models cannot identify the diffusion mechanism of adsorption. Generally, bulk diffusion and adsorption are assumed to be rapid and not ratedetermining [31]. Therefore, the kinetic data were also analyzed using the intraparticle diffusion model in describing the diffusion mechanism. This is important in considering the diffusion mechanism between MG molecules and MWCNTs as MWCNTs have porous structure. The intraparticle diffusion model equation is given by Eq. 11 below:

$$
Q_{t}=K_{d i f f} t^{1 / 2}+C
$$

where $k_{\text {diff }}$ is intraparticle diffusion rate constant $\left(\mathrm{mg} / \mathrm{g} \mathrm{min}^{1 / 2}\right)$ and $C$ is the intercept. The value of $k_{\text {diff }}$ and $C$ value of intraparticle diffusion were obtained from the slope and intercept of plot $Q_{t}$ versus $t^{1 / 2}$ [23]. The data from adsorption of MG by MWCNTs at mass of $0.03 \mathrm{~g}$ were examined and experimental data are presented in Table 5 . The best-fit model was selected based on the linear regression correlation coefficient values $\left(R^{2}\right)$.

Table 6. Linear regression of kinetic adsorption and its constant parameter

\begin{tabular}{lllc}
\hline Model & Linear regression & Parameter & Value of parameter \\
\hline Pseudo first-order & $\mathrm{y}=-0.0235 \mathrm{x}+1.7648$ & $k_{1}$ & 0.054 \\
& & $Q_{e}$ (calc) & 58.184 \\
& & $Q_{e}(\mathrm{exp})$ & 85.700 \\
Pseudo second-order & $\mathrm{y}=0.0114 \mathrm{x}+0.0746$ & $R^{2}$ & 0.916 \\
& & $k_{e}$ (calc) & 0.0017 \\
& & $Q_{e}(\mathrm{exp})$ & 87.719 \\
& & $R^{2}$ & 85.700 \\
Intraparticle diffusion & $\mathrm{y}=11.093 \mathrm{x}+16.136$ & $k_{\text {diff }}$ & 0.978 \\
& & $C$ & 11.093 \\
& & $R^{2}$ & 16.136 \\
\hline
\end{tabular}




\section{Siti Aminah et al: REMOVAL OF MALACHITE GREEN DYE FROM AQUEOUS SOLUTION USING MULTI-WALLED CARBON NANOTUBES: AN APPLICATION OF EXPERIMENTAL DESIGN}

Table 5 presents the kinetic parameter for the adsorption of MG by MWCNTs. Both of $R^{2}$ values of pseudo-first-order and pseudo-second-order have a good correlation coefficient; however, pseudo-second-order showed a better result as pseudo-second-order has higher $R^{2}(0.978)$ compared to pseudo-first-order $(0.916)$. In addition, the value of $Q_{e}$ (calc) derived from pseudo-second-order is comparatively much closer to $Q_{e}$ (exp).

For intraparticle diffusion model, the plot of $Q_{t}$ versus $t^{1 / 2}$ should give a linear plot if intraparticle diffusion participated in the adsorption and the intraparticle diffusion is the only rate-controlling step if the line of linear regression passes through the origin [34]. Otherwise, there are other mechanisms that also contributed to intraparticle diffusion. The $C$ value of intraparticle diffusion is also helpful in boundary thickness; a larger $C$ corresponds to a greater boundary layer diffusion effect [31]. Besides, the larger value of the intercept also shows the greater surface adsorption that contributes to the rate-controlling step [33]. The regression $\left(\mathrm{Q}_{t}\right.$ versus $\left.\mathrm{t}^{1 / 2}\right)$ of $\mathrm{MG}$ removal by MWCNTs showed a linear plot; however, the line did not pass through the origin. This indicates that the adsorption involved in intraparticle diffusion was not only rate-controlling step [34].

\section{Conclusion}

The present study showed that the MG dye from aqueous solution was successfully removed by MWCNTs and the adsorption condition was efficiently optimized by applying central composite design. The adsorption MG by MWCNT achieved optimum removal in equilibrium time of 17 minutes with $20 \mathrm{ppm}$ of initial dye concentration, $0.03 \mathrm{~g}$ of mass of MWCNT, $\mathrm{pH} 7$ and agitation speed of 150 strokes $/ \mathrm{min}$. Analysis of variance also showed a good coefficient of determination $\left(\mathrm{R}^{2}=0.922\right)$, ensuring that the model was well-fitted. Central composite design successfully proved the significance of all the experimental factors which affect the rate of the adsorption. The isotherm and kinetic of adsorption were also investigated. For the isotherm model, both Langmuir and Freundlich models were fitted with experimental equilibrium data but the results showed the Langmuir model $\left(\mathrm{R}^{2}=0.998\right)$ is best fitted for the concentration range studied. The maximum adsorption capacity of MWCNTs for MG dye was 112.36 $\mathrm{mg} \mathrm{g}^{-1}$. The experimental data depicted that the adsorption kinetic of MG by MWCNTs was controlled by pseudosecond-order kinetic model $\left(\mathrm{R}^{2}=0.978\right)$ with rate constant calculated at $0.0017 \mathrm{~g} \mathrm{mg}^{-1} \mathrm{~min}^{-1}$.

\section{Acknowledgement}

The authors express their appreciation to Centre for Water Research and Analysis staffs for providing facilities during this study.

\section{References}

1. Buthelezi, S.P., Olaniran, A.O., and Pillay, B. (2012). Textile dye removal from wastewater effluents using bioflocculants produced by indigenous bacterial isolates. Molecules, 17(12): 14260 - 14274.

2. Sudova, E., Machova, J., Svobodova, Z., and Vesely, T. (2007). Negative effects of malachite green and possibilities of its replacement in the treatment of fish eggs and fish: A review. Veterinarni Medicina, 52(12): 527-539.

3. Culp, S. and Beland, F. (1996). Malachite green: A toxicological review. International Journal of Toxicology, 15(3): 219-238.

4. Srivastava, S., Sinha, R., and Roy, D. (2004). Toxicological effects of malachite green. Aquatic Toxicology, 66(3): 319-329.

5. Culp, S.J., Mellick, P.W., Trotter, R.W., Greenlees, K.J., Kodell, R.L., and Beland, F.A. (2006). Carcinogenicity of malachite green chloride and leucomalachite green in B6C3F1 mice and F344 rats. Food and Chemical Toxicology, 44(8): 1204-1212.

6. Hidayah, N., Abu Bakar, F., Nur-Azura, M.S., Mahyudin, N.A., Zaman, M.Z., and Faridah, S. (2013). Detection of malachite green and leuco-malachite green in fishery industry. International Food Research Journal, 20(4): 1511-1519.

7. Mitrowska, K., Posyniak, A., and Zmudzki, J. (2007). The effects of cooking on residues of malachite green and leucomalachite green in carp muscles. Analytica Chimica Acta, 586(1-2): 420-425.

8. Cho, B.P., Yang, T., Blankenship, L.R., Moody, J.D., Churchwell, M., Beland, F.A., and Culp, S.J. (2003). Synthesis and characterization of N-Demethylated metabolites of malachite green and leucomalachite green. Chemical Research in Toxicology, 16(3): 285-294. 
9. Derakhshan, M.S. and Moradi, O. (2014). The study of thermodynamics and kinetics methyl orange and malachite green by SWCNTs, SWCNT-COOH and SWCNT-NH $\mathrm{N}_{2}$ as adsorbents from aqueous solution. Journal of Industrial and Engineering Chemistry, 20(5): 3186-3194.

10. Madrakian, T., Afkhami, A., Ahmadi, M., and Bagheri, H. (2011). Removal of some cationic dyes from aqueous solutions using magnetic-modified multi-walled carbon nanotubes. Journal of Hazardous Materials, 196: 109114.

11. Aksu, Z. (2005). Application of biosorption for the removal of organic pollutants: A review. Process Biochemistry, 40(3-4): 997-1026.

12. Robinson, T., McMullan, G., Marchant, R., and Nigam, P. (2001). Remediation of dyes in textile effluent: A critical on current treatment technologies with a propose alternative. Bioresource Technology, 77: 247-255.

13. Wu, C.H. (2007). Adsorption of reactive dye onto carbon nanotubes: Equilibrium, kinetics and thermodynamics. Journal of Hazardous Materials, 144(1-2): 93-100.

14. Ren, X., Chen, C., Nagatsu, M., and Wang, X. (2011). Carbon nanotubes as adsorbents in environmental pollution management: A review. Chemical Engineering Journal, 170(2-3): 395-410.

15. Gupta, V.K., Kumar, R., Nayak, A., Saleh, T.A., and Barakat, M.A. (2013). Adsorptive removal of dyes from aqueous solution onto carbon nanotubes: A review. Advances in Colloid and Interface Science, 193-194: 24-34.

16. Gupta, V.K., Agarwal, S., and Saleh, T.A. (2011). Chromium removal by combining the magnetic properties of iron oxide with adsorption properties of carbon nanotubes. Water Research, 45(6): 2207-2212.

17. Li, Y.H., Ding, J., Luan, Z., Di, Z., Zhu, Y., Xu, C., Wu, D., and Wei, B. (2003). Competitive adsorption of $\mathrm{Pb}^{2+}$, $\mathrm{Cu}^{2+}$ and $\mathrm{Cd}^{2+}$ ions from aqueous solutions by multiwalled carbon nanotubes. Carbon, 41(14): 2787-2792.

18. Clément, P., Hafaiedh, I., Parra, E.J., Thamri, A., Guillot, J., Abdelghani, A., and Llobet, E. (2014). Iron oxide and oxygen plasma functionalized multi-walled carbon nanotubes for the discrimination of volatile organic compounds. Carbon, 78: 510-520.

19. Kerkez, Ö. and Bayazit, SS.S. (2014). Magnetite decorated multi-walled carbon nanotubes for removal of toxic dyes from aqueous solutions. Journal of Nanoparticle Research, 16(6): 1-11.

20. Yao, Y., Xu, F., Chen, M., Xu, Z., and Zhu, Z. (2010). Adsorption behavior of methylene blue on carbon nanotubes. Bioresource Technology, 101(9): 3040-3046.

21. Bezerra, M.A., Santelli, R.E., Oliveira, E.P., Villar, L.S., and Escaleira, L.A. (2008). Response surface methodology (RSM) as a tool for optimization in analytical chemistry. Talanta, 76(5): 965-977.

22. Ravikumar, K., Deebika, B., and Balu, K. (2005). Decolourization of aqueous dye solutions by a novel adsorbent: Application of statistical designs and surface plots for the optimization and regression analysis. Journal of Hazardous Materials, 122(1-2): 75-83.

23. Roosta, M., Ghaedi, M., Shokri, N., Daneshfar, A., Sahraei, R., and Asghari, A. (2014). Optimization of the combined ultrasonic assisted/adsorption method for the removal of malachite green by gold nanoparticles loaded on activated carbon: experimental design. Spectrochimica Acta Part A: Molecular and Biomolecular Spectroscopy, 118: 55-65.

24. Ghaedi, M., Mazaheri, H., Khodadoust, S., Hajati, S., and Purkait, M.K. (2015). Application of central composite design for simultaneous removal of methylene blue and $\mathrm{Pb}^{2+}$ ions by walnut wood activated carbon. Spectrochimica Acta Part A: Molecular and Biomolecular Spectroscopy, 135: 479-490.

25. Roosta, M., Ghaedi, M., Daneshfar, A., Darafarin, S., Sahraei, R., and Purkait, M.K. (2014). Simultaneous ultrasound-assisted removal of sunset yellow and erythrosine by $\mathrm{ZnS}: \mathrm{Ni}$ nanoparticles loaded on activated carbon: Optimization by central composite design. Ultrasonic Sonochemistry, 21(4): 1441-1450.

26. Ghaedi, M. and Mosallanejad, N. (2014). Study of competitive adsorption of malachite green and sunset yellow dyes on cadmium hydroxide nanowires loaded on activated carbon. Journal of Industrial and Engineering Chemistry, 20(3): 1085-1096.

27. Khataee, A.R., Fathinia, M., Aber, S., and Zarei, M. (2010). Optimization of photocatalytic treatment of dye solution on supported $\mathrm{TiO} 2$ nanoparticles by central composite design: Intermediates identification. Journal of Hazardous Materials, 181(1-3): 886-897.

28. Ghaedi, M., Ansari, A., Habibi, M.H., and Asghari, A.R. (2014). Removal of malachite green from aqueous solution by zinc oxide nanoparticle loaded on activated carbon: Kinetics and isotherm study. Journal of Industrial and Engineering Chemistry, 20(1): 17-28. 
Siti Aminah et al: REMOVAL OF MALACHITE GREEN DYE FROM AQUEOUS SOLUTION USING MULTI-WALLED CARBON NANOTUBES: AN APPLICATION OF EXPERIMENTAL DESIGN

29. Shirmardi, M., Mahvi, A.H., Hashemzadeh, B., Naeimabadi, A., Hassani, G., and Niri, M.V. (2013). The adsorption of malachite green (MG) as a cationic dye onto functionalized multi walled carbon nanotubes. Korean Journal of Chemical Engineering, 30(8): 1603-1608.

30. Gholizadeh, A., Kermani, M., Gholami, M., Farzadkia, M., and Yaghmaeian, K. (2013). Removal efficiency, adsorption kinetics and isotherms of phenolic compounds from aqueous solution using rice bran ash. Asian Journal of Chemistry, 25(7): 3871-3878.

31. Farghali, A.A., Bahgat, M., ElRouby, W.M.A., and Khedr, M.H. (2013). Decoration of multi-walled carbon nanotubes (MWCNTs) with different ferrite nanoparticles and its use as an adsorbent. Journal of Nanostructure in Chemistry, 3(50): 1-12.

32. Tang, W.W., Zeng, G.M., Gong, J.L., Liu, Y., Wang, X.Y., Liu, Y.Y., Liu, Z.F., Chen, L., Zhang, X.R., and Tu, D.Z. (2012). Simultaneous adsorption of atrazine and $\mathrm{Cu}$ (II) from wastewater by magnetic multi-walled carbon nanotube. Chemical Engineering Journal, 211-212: 470-478.

33. Bahgat, M., Farghali, A.A., El Rouby, W., Khedr, M., and Mohassab-Ahmed, M.Y. (2012). Adsorption of methyl green dye onto multi-walled carbon nanotubes decorated with Ni nanoferrite. Applied Nanoscience, 3(3): 251261.

34. Khani, M.H. (2011). Uranium biosorption by Padina sp. algae biomass: Kinetics and thermodynamics. Environmental Science Pollution Research, 18(9): 1593-1605. 